\title{
RURAL DEVELOPMENT IN THE SKOPJE PLANNING REGION IN THE REPUBLIC OF NORTH MACEDONIA THROUGH ENTREPRENEURSHIP
}

\author{
Tošo Kostadinov \\ Institute of Animal Science, Ss. Cyril and Methodius University in Skopje, \\ Blvd. Ilinden 92a, Skopje, Republic of North Macedonia \\ tosokostadinov@gmail.com
}

\begin{abstract}
A b s t r a c t: The aim of this paper is to include new knowledge about entrepreneurship in the rural areas of the Skopje planning region in the Republic of North Macedonia. 21 SME (small and mid-size enterprise) owners in the rural areas of the region were interviewed and five sets of claims were presented that are important for understanding the entrepreneurial situation in the rural areas of the region. The situation with entrepreneurship and SMEs in the region is compared with similar results for the state of entrepreneurship in rural areas of the country. One of the conclusions is that the rural entrepreneur in the Skopje planning region has unsatisfactory entrepreneurial qualities needed for developed businesses in terms of commitment, desire for independence, flexibility and more. The main priorities of the development of the Skopje planning region are: 1) Modern transport, communal and energy infrastructure with full protection of the environment. 2) Healthy and protected environment. 3) Use of funds from the IPA instrument. 4) Increasing the level of economic development of the region by encouraging and developing SMEs, leading industries and exploiting the competitive advantages of the region. 5) Better use and improvement of human capital for economic purposes and improving the quality of health and social protection. 6) Promotion of modern agriculture and sustainable rural development. 7) Use of the natural and cultural-historical heritage in function of tourism development. 8) Greater coverage of the Skopje region with spatial planning documentation and its fast and effective documentation.
\end{abstract}

Key words: Skopje planning region; entrepreneurship; entrepreneurs; rural areas; SMEs

\section{РУРАЛНИОТ РАЗВОЈ ВО СКОПСКИОТ ПЛАНСКИ РЕГИОН ВО РЕПУБЛИКА СЕВЕРНА МАКЕДОНИЈА НИЗ ПРЕТПРИЕМАШТВО}

А п с т р а к т: Целта на овој труд е да се вклучат нови знаења за претприемаштвото во руралните подрачја на Скопскиот плански регион во Република Северна Македонија. Интервјуирани се 21 сопственик на МСП (мали и средни претпријатија) во руралните области на регинот и се презентирани другите пет групи на тврдења кои се важни за разбирање на ситуацијата со претприемаштвото во руралните области на регионот. Состојбата со претприемаштвото и МСП во регионот е компарирана со истоветни резултати за состојбата на претприемаштвото во другите рурални области на државата. Еден од заклучоците е дека руралниот претприемач во Скопскит плански регион има незадоволувачки претприемачки квалитети потребни за развиените бизниси во однос на посветеност, желба за независност, флексибилност и друго. Главни приоритети на развојот на Скопскиот плански регион се: 1) Современа транспортна, комунална и енергетска инфраструктура со целосна заштита на животната средина. 2) Здрава и заштитена животна средина. 3) Користење на средства од инструментот за пристап на помош (ИПА). 4) Зголемување на нивото на економска развиеност на регионот преку поттикнување и развој на МСП, носечките индустрии и искористување на конкурентните предности на регионот. 5) Поквалитетно искористување и унапредување на човечкиот капитал за стопански цели и унапредување на квалитетот на здравствената и социјална заштита. 6) Промоција на модерно земјоделство и оддржлив рурален развој. 7) Оптимално користење на природното и културно-историско наследство во функција на развој на туризмот. 8) Поголема покриеност на Скопскиот регион со просторно-планска документација и нејзина брза и ефективна документација.

Клучни зборови: Скопски плански регион; претприемаштво; претприемачи: рурални области; МСП 


\section{INTRODUCTION}

The Skopje planning region covers the basin of the Skopje valley and covers a total area of $1812 \mathrm{~km}^{2}$ or $7 \%$ of the territory of the Republic of North Macedonia. The planning region consists of 17 municipalities (10 of which are part of the city of Skopje) and the city of Skopje, as a separate unit of local self-government, with a total of 601057 inhabitants.

The population density is 319 inhabitants $/ \mathrm{km}^{2}$ and is four times higher than the national average (81 inhabitants per $\mathrm{km}^{2}$ ). The city of Skopje is concentrated around $71.8 \%$ of the population in the region, i.e. $25.1 \%$ of the total population in the country, which indicates the huge concentration of population in the Skopje agglomeration [1].

There is one border crossing in the Skopje planning region, Blace with Kosovo and an international airport.

\section{Natural resources}

The conditions for development of agriculture in the Skopje planning region are quite limited due to the high level of urbanization and the large fragmentation of agricultural crops, which does not support the development of intensive agricultural production. In this region, cereal crops and to some extent viticulture are mainly present, while industrial crops are very little represented and there is no greater potential for their spread.

From the explored ore deposits so far, the deposits of chrome ores in Raduša (in the municipality of Saraj) have the most important economic significance, and from the non-mental revivals the most important are the decorative stones and travertines in Kučkovo and Svilare. The thermal and thermo-mineral waters in Katlanovo have a special mineralogical significance, which give an opportunity for development of the spa tourism in this area.

The main water resource in the Skopje planning region is the river of Vardar, with the tributaries Treska, Lepenec, Pčinja, Markova River and Kadina River. Two accumulations, Matka 1 and Kozjak, have been built on the river of Treska, and Matka 2 is under construction. Besides the hydropower potential, Treska and Kadina rivers with their ambient beauties offer excellent conditions for recreation and development of touristic and catering contents [2].

\section{Natural and cultural-historical heritage}

From the natural and cultural historical heritage in the Skopje planning region, according to its tourist potential, the archeological site Skupi, the fortress Kale, the aqueduct, the old city bazaar in the city of Skopje, numerous churches and mosques and several nature reserves and natural monuments, with Matka and Lake Treska having the biggest touristic potential. [3]

\section{Economic characteristics}

The Skopje planning region is by far the most developed region in the Republic of North Macedonia and participates with $45.5 \%$ in the creation of the Macedonian GDP. The planning region has a GDP of 5150 euros (2019, third quarter) which is $55.8 \%$ higher than the average of the country. Carriers of the economic development of the planning region are the food industry, textile, printing, metal processing, construction, catering, trade, transport and business services [7].

\section{Development priorities}

The main priorities of the development of the Skopje planning region are [8]:

- Modern transport, communal and energy infrastructure with complete protection of the environment.

- Healthy and protected environment.

- Use of funds from the IPA instrument.

- Increasing the level of economic development of the region by encouraging and developing SMEs, leading industries and taking advantage of the competitive advantages of the region.

Better use and promotion of human capital for economic purposes and improvement of the quality of health and social protection.

- Promotion of modern agriculture and sustainable rural development.

- Optimal use of natural and cultural-historical heritage in order to develop tourism

- Greater coverage of the Skopje region with spatial planning documentation and its fast and effective documentation.

\section{MATERIALS AND METHODS}

The aim of this research is based on relevant literature, documents and particularly an analysis of relevant sample of interviews (owners of 21 
SMEs) to observe the conditions of the Skopje planning region. The comparision of the obtained results with those relevant to the whole territory off the Republic of North Macedonia (interviewed suitable sample of 133 SMEs) put more light on the entrepreeurship in the researched region.

Several commonly used methods of economic analysis were applied in the composition of this work, primarily the method of generalization and specialization, the method of induction and deduction, statistical method and the comparative method.

\section{RESULTS AND DISCUSSION}

Five sets of statements (valued at a five-degree scale from 1 - unimportant, to 5 - priority) that are of relevance to the efforts to perceive the situation of rural entrepreneurship were presented to the survey respondents in the Skopje planning region of the Republic of North Macedonia. (Tables 1, 2, 3, 4 and 5).
The results are compared to those obtained from rural areas on the territory of the Republic of North Macedonia.

The most important measures in terms of improving the competitiveness of companies in the market are assistance from development programs through grants, assistance from development programs through favorable loans, improving product promotion, and the quality of products / services. Respondents are aware of the benefits of obtaining / owning quality certificates.

The next measures in the ranking are training and education in the field of marketing, sales, informatics, entrepreneurship, management, as well as assistance from development programs through guarantee funds.

The lowest ranked needs are the professional consulting assistance, training and education in the field of foreign languages, and as the last idea of the offered, the respondents state the association with the companies from the same sector in order to jointly enter the market.

Table 1

Degree of agreement of the claims from the aspect of improving the market competitiveness with the help of arithmetic means

\begin{tabular}{llc}
\hline \hline & Average value (rural areas) \\
& $\begin{array}{c}\text { Republic of North } \\
\text { Macedonia }\end{array}$ & $\begin{array}{c}\text { Skopje planning } \\
\text { region }\end{array}$ \\
\hline Improving the quality of products / services & 4.14 & 4.14 \\
Improving product promotion & 4.23 & 4.06 \\
Obtaining quality certificates & 4.06 & 3.96 \\
Professional consulting assistance & 3.43 & 3.37 \\
Training and education in the field of entrepreneurship & 3.86 & 3.79 \\
Training and education in the field of informatics & 3.91 & 3.73 \\
Training and education in the field of management & 3.80 & 3.49 \\
Training and education in the field of finance & 3.62 & 3.76 \\
Training and education in the field of sales & 3.86 & 4.80 \\
Training and education in the field of marketing & 3.91 & 3.18 \\
Training and education in the field of foreign languages & 3.38 & 3.19 \\
Associating with companies from my sector in order to jointly enter the market & 3.34 & 4.20 \\
Help with development programs through grants & 4.33 & 3.16 \\
Assistance from development programs through favorable loans & 3.82 & \\
Assistance from development programs through guarantee funds & & \\
\hline \hline
\end{tabular}

Source: Own calculations 
Table 2

Degree of agreement of the statements in terms of future business plans with the help of arithmetic means

\begin{tabular}{|c|c|c|}
\hline & \multicolumn{2}{|c|}{ Average value (rural areas } \\
\hline & Republic of North Macedonia & Skopje planning region \\
\hline Adding a new product or service & 4.10 & 3.95 \\
\hline Selling in a new market & 3.34 & 3.10 \\
\hline Exploring new markets & 3.37 & 3.14 \\
\hline Finding new distribution channels & 3.62 & 3.50 \\
\hline Expand advertising and promotion & 3.87 & 3.60 \\
\hline Investing in new devices / machines & 3.68 & 3.55 \\
\hline Replacement of current devices / machines & 3.75 & 3.53 \\
\hline Expansion of current plants & 3.68 & 3.59 \\
\hline Redesign / new layout of current plants & 3.42 & 3.34 \\
\hline Request for additional financial capital & 3.98 & 3.85 \\
\hline Computerization of current operations & 3.29 & 3.03 \\
\hline Upgrading computer systems & 3.48 & 3.28 \\
\hline Redesign of work activities & 3.25 & 3.12 \\
\hline Expanding the scope of work activities & 3.77 & 3.60 \\
\hline Seek professional or technical advice & 3.45 & 13.33 \\
\hline Additional engagement of employed specialists & 3.38 & 3.22 \\
\hline Investing in employee training (elsewhere / not in the company) & 2.63 & 2.45 \\
\hline
\end{tabular}

Source: Own calculations

One of the main policies for the development of rural entrepreneurship as a driver of sustainable development in rural areas is education and providing business counseling services [4]. It is necessary to conduct education in rural areas through four groups of skills of the educational program [5]:

- scientific and technical skills,

- management skills,

- entrepreneurial skills and

- business skills. '

Respondents believe that adding a new product or service, requesting additional financial capital and expanding advertising and promotion are planned activities in their companies in the next two years.

Next on the list of short-term priorities are expanding the scope of work activities, replacing current devices / machines, investing in new devices / machines, expanding existing plants and finding new distribution channels
Investing in employee training elsewhere than in the company is the last thing respondents plan to do soon.

The attitude of the respondents who would rather have their own business than earn a higher salary by working for someone else is assessed most positively.

Respondents point out that they would like to significantly contribute to the community by developing a successful business, while being aware that it is important for the entrepreneur to understand and accept the risk to start and run a successful business. There is agreement with the view that business is the most important activity in the life of entrepreneurs, and for a successful business, they would do whatever it takes.

There is a high degree of agreement among entrepreneurs who run their business to improve the status and prestige of their family and to have more flexibility in their personal and family life. 
They would rather have their own business than have another promising career.

The entrepreneurs surveyed do not agree with the claim that selling their business is part of their plan.

Similar results are given by the researched issues and other researchers and note the benefits of the development of rural entrepreneurship [4]:
- possibility of self-employment,

- stopping migration from rural to urban areas,

- balanced regional development,

- encouraging the lives of young people in rural areas,

- support of the living standard in the rural areas,

- increase of the income of the population.

\section{Table 3}

Degree of agreement of the statements from the aspect of the attitudes for entrepreneurship with the help of the arithmetic means

\begin{tabular}{lcc}
\hline \hline & $\begin{array}{c}\text { Average value (rural area) } \\
\text { Mepublic of North } \\
\text { Macedonia }\end{array}$ & $\begin{array}{c}\text { Skopje planning } \\
\text { region }\end{array}$ \\
\hline My business is the most important activity in my life & 4.16 & 4.03 \\
I would do whatever it takes for my business to succeed & 4.17 & 4.00 \\
I plan to sell the business in the end & 2.15 & 2.36 \\
I would like to contribute significantly to the community by developing a successful business & 4.31 & 4.12 \\
I would rather have my own business than earn a higher salary by working for someone else & 4.77 & 4.56 \\
Running your own business is more important than having more time for your family & 3.80 & 3.64 \\
I would rather have my own business than have another promising career & 4.10 & 3.92 \\
It is important for the entrepreneur to understand and accept the risk to start and run & 4.23 \\
$\quad$ a successful business & 3.76 \\
I am ready to enter into conflict with my family to run my business & 3.53 & 4.10 \\
I would mortgage my house to provide capital for my business & 3.67 & 3.57 \\
I would be willing to have less security for my family to run my business & 3.34 & 3.37 \\
I run my own business to continue the family tradition & 3.52 \\
I run my own business to contribute to the well-being of my relatives & 3.48 \\
I run my business to live in a place that my family wants & 4.02 \\
I run my business to improve the status and prestige of my family & 4.10 \\
I run my business to have more flexibility in my personal and family life & 3.37 \\
\hline \hline
\end{tabular}

Source: Own calculations

Table 4

Degree of agreement of the claims from the aspect of the attitudes in the community towards the entrepreneurs with the help of the arithmetic means

\begin{tabular}{|c|c|c|}
\hline & \multicolumn{2}{|c|}{ Average value (rural area) } \\
\hline & $\begin{array}{l}\text { Republic of North } \\
\text { Macedonia }\end{array}$ & $\begin{array}{l}\text { Skopje planning } \\
\text { region }\end{array}$ \\
\hline $\begin{array}{l}\text { Many people in my community (municipality) understand that entrepreneurs are crucial to the } \\
\text { future of our community. }\end{array}$ & 2.77 & 2.23 \\
\hline $\begin{array}{l}\text { Many people in my community really support entrepreneurs when they fail and start a new } \\
\text { business. }\end{array}$ & 2.67 & 2.18 \\
\hline $\begin{array}{l}\text { Many people in my community support someone who is creating a new or expanding existing } \\
\text { business. }\end{array}$ & 2.63 & 2.31 \\
\hline $\begin{array}{l}\text { Many people in my community would encourage a younger person to pursue a career } \\
\text { in creating and growing a business. }\end{array}$ & 3.01 & 2.90 \\
\hline Many people in my community would love to start and grow a business & 2.94 & 2.76 \\
\hline
\end{tabular}

Source: Own calculations 
Respondents are not sure that many people in their community would encourage a younger person to pursue a career in creating and growing a business. At the same time, it is the most positively assessed attitude in the community. A lower degree of agreement is given to the statement that many people in their community would like to start and grow a business, probably because many people in their community (municipality) do not fully understand that entrepreneurs are crucial to the future of their community.

From the answers it can be concluded that there is not a sufficient degree of agreement that many of the people in the respondent community really support entrepreneurs when they fail and try a new business again.

The lowest ranked attitude of this group is that many people in the community support some- one who creates a new or expands an existing business.

The development of entrepreneurship in rural areas implies the creation of an entrepreneurial climate, i.e. encouraging entrepreneurial behavior [5]. Achieving the following several goals contributes to the active development of rural entrepreneurship [6]:

- creating conditions for training of entrepreneurship in rural areas,

- encouraging the population to actively participate in the plans of rural entrepreneurship,

- encouraging governmental and non-governmental organizations to support entrepreneurial activities,

- establishment of active economy management.

Table 5

Degree of claims from the aspect of supporting entrepreneurship with the help of arithmetic means

\begin{tabular}{lcc}
\hline \hline & $\begin{array}{c}\text { Average value (rural area) } \\
\text { Republic of North } \\
\text { Macedonia }\end{array}$ & $\begin{array}{c}\text { Skopje } \\
\text { planning region }\end{array}$ \\
\hline $\begin{array}{l}\text { My community respects and celebrates the people who create and grow local businesses } \\
\text { My community has developed programs to encourage and support entrepreneurs involved } \\
\text { in development and growth }\end{array}$ & 2.82 & 2.67 \\
$\begin{array}{l}\text { My community is considering micro-lending programs } \\
\text { My community offers business or entrepreneurship training }\end{array}$ & 2.69 & 2.35 \\
$\begin{array}{l}\text { My community creates conditions for networking and monitoring opportunities } \\
\text { for entrepreneurs and local businesses }\end{array}$ & 2.66 & 2.40 \\
My community needs venture capital and / or angelinvestors & 2.56 & 2.70 \\
\hline \hline
\end{tabular}

Source: Own calculations.

The highest score of the respondents related to the support of entrepreneurship is that the community needs venture capital and / or angels-investors.

Respondents are not convinced that the community offers business or entrepreneurship training, that it respects and celebrates the people who create and grow local businesses, and is skeptical about thinking about micro-lending programs as well as encouraging and supporting entrepreneurs involved in development. and growth.

The lowest rated attitude of this group is related to the creation of conditions for networking and monitoring of opportunities for entrepreneurs and local business people.

\section{CONCLUSION}

In comparison with the results from the survey of SMEs in rural areas on the whole territory of the Republic of North Macedonia, SMEs in rural areas of the Skopje planning region still seem to be less competitive.

The results of the comparative analysis have shown that owners have expressed a lower degree of consideration regarding future plans for their own businesses of SMEs (Skopje planning region) than their average counter from rural areas of the Republic of North Macedonia.

Generally speaking, the responses to the set of questions regarding attitudes towards entrepreneur- 
ship indicate relatively positive attitudes towards entrepreneurship. However, the responses of SMEs in rural areas of the Skopje planning region indicate that the attitudes towards entrepreneurship among SMEs in that region are less positive than the views expressed by respondents from SMEs in rural areas throughout the territory of the Republic of North Macedonia.

The main priorities of the development of the Skopje planning region are:

- Modern transport, communal and energy infrastructure with complete protection of the environment.

- Healthy and protected environment.

- Use of funds from the IPA instrument.

- Increasing the level of economic development of the region by encouraging and developing SMEs, leading industries and taking advantage of the competitive advantages of the region.

- Better use and promotion of human capital for economic purposes and improvement of the quality of health and social protection.

- Promotion of modern agriculture and sustainable rural development.

- Optimal use of natural and cultural-historical heritage in order to develop tourism.
- Greater coverage of the Skopje region with spatial planning documentation and its fast and effective documentation.

\section{REFERENCES}

.[1] Center on Development of Skopje Planning Region: Program for development on the Skopje planning region, 2015-2019, Skopje, 2014.

.[2] Center on Development of Skopje Planning Region: Action plan for implementation of the program for 2020, Skopje, 2019.

[3] Center on Development of Skopje Planning Region: Annual report on implementation of the program for development of Skopje planning region for 2019, Skopje, 2018.

[4] Cifrić, I.: Okoliš i održlivi razvoj - ugroženost okoliša i estetika krajolika. Društvena istražuvanja: Časopis za opća društvena pitanja: 12 (3-4), pp. 61-70, 2003.

[5] Čavrak, V.: Održivi razvoj ruralnih područja Hrvatske, Zbornik Ekonomskog fakulteta u Zagrebu, 1 (1), pp. 162171, 2003.

[6] Defilippis, J.: Poljoprivreda i razvoj, Šolska knjiga, Zagreb, 2005.

[7] ISPI: Strategy, Policy and Management of Rural Development in the Republic of Macedonia, Tribina Makedonska, Skopje, 1998.

[8] Ministry of Local Self-Government of the Republic of Macedonia: Planning Regions in the Republic of Macedonia, Skopje, 2011. 
